\title{
BACTERIOLOGICAL ASPECTS OF SEWAGE PURIFICATION AND RIVER POLLUTION
}

\author{
By PAUL KELLER \\ Senior Research Officer and Head of the Division of Bacteriology, \\ National Institute for Water Research, South African Council \\ for Scientific and Industrial Research
}

(With 2 Figures in the Text)

\section{INTRODUCTION}

Rapid industrial development in South Africa has resulted in an increasing demand for water for all purposes. Consequently it has become urgent to consider the role of purified sewage and industrial effluents in the conservation of water supplies. On the Witwatersrand, the main industrial area of the country, and in other major industrial centres the flow of sewage reaching the various sewage purification plants constitutes as much as $75 \%$ of the total water consumption.

The possibility of an unrestricted re-use of properly purified sewage effluents, and the prevention of bacterial pollution arising from the discharge of sewage effluents under conditions peculiar to the country, necessitated a critical study of the efficiency of conventional sewage purification plants in eliminating faecal pollution. Furthermore, purified sewage effluents from plants treating sewage to the humus tank and sand-filter stages cannot be discharged as such into rivers whose self-purification powers are limited by low flow rates and by lack of sufficient dilution water during the long dry seasons. Moreover, the fate of sewage bacteria after discharge into a river system required evaluation with particular reference to the relative significance of bacterial pollution contributed by drainage, run-off and storm water from populated and unpopulated areas during dry and rainy seasons.

The necessity of reducing the concentration of faecal organisms in sewage effluents beyond that obtained by sand filtration resulted in experiments with a variety of biological purification units (Stander \& Gien, 1956). Experimental work consisted essentially in the passage of sand-filter and/or humus tank effluent through grass beds, ponds with a dense growth of vegetation (frequently found occurring naturally in South Africa and known as vleis), algal beds, model or artificial rivers, and maturation or oxidation ponds.

\section{METHODS OF ANALYSIS}

The results presented and discussed here are concerned exclusively with the bacteriological aspects of the problem.

In this presentation the term pollution always denotes sewage and/or faecal pollution unless it is specifically stated that a different type of pollution is referred to. 
The methods of bacteriological analysis used for routine purposes were adopted after comparative studies of the suitability of a number of accepted and tentative media for the detection and enumeration of organisms occurring in sewage, sewage effluents and sewage-polluted streams, most of which are members of the 'coliform group'. In this comparative study, use was made of the 'Indole-Methyl-RedVoges Proskauer-Citrate' reactions (IMVIC) to ascertain the type of organisms isolated and numerically determined. In the routine laboratory analysis, Koser's citrate medium is used for mixed populations since it had been found, particularly in the analysis of river-water samples, that significant information as to the presence and relative prevalence of coliform organisms of possibly non-faecal origin could be obtained.

The combination of media used for routine purposes, which will be discussed below, is as follows:

(1) Nutrient agar at $37^{\circ} \mathrm{C}$. for $48 \mathrm{hr}$., to determine the 'total count', i.e. the total number of viable organisms present in the original sample which are capable of growing under the conditions of test. Of necessity, this value is relative, since with variations in temperature and duration of incubation the number of organisms will vary.

(2) Lactose broth at $37^{\circ} \mathrm{C}$. for $48 \mathrm{hr}$., usually with a second reading after $96 \mathrm{hr}$. incubation in the case of samples of water and bottom sediments from rivers, to determine the number of organisms capable of fermenting lactose with the production of gas, to differentiate between lactose fermenters generally on the one hand, and slow lactose fermenters on the other hand, and to demonstrate the possible occurrence of false positives and their relative significance.

(3) Brilliant green bile-salt lactose broth at $37^{\circ} \mathrm{C}$. for $48 \mathrm{hr}$. to determine the number of organisms belonging to the coliform group.

(4) MacConkey broth at $44 \cdot 5^{\circ} \mathrm{C}$. for $48 \mathrm{hr}$. to determine the number of typical faecal Escherichia coli.

(5) Koser's citrate medium at $37^{\circ} \mathrm{C}$. for $48 \mathrm{hr}$. to determine the presence and relative prevalence of members of the coliform group which may not be of faecal origin, and whose incidence plays a significant part in the study of river-water and potential raw-water supplies.

(6) Buffered azide glucose glycerol (BAGG) broth at $37^{\circ} \mathrm{C}$. for $48 \mathrm{hr}$. to determine the number of faecal streptococci.

These media are used in parallel; no re-inoculations are required. To maintain a constant standard, only dehydrated media of one commercial brand have been used.

With the exception of 'total counts', all figures are derived from 'Most Probable Numbers'. All figures refer to the number of organisms per ml. of original sample. Results were usually calculated either for definite seasons, or for 'cycles', i.e. periods of time during which conditions of an experimental run were assumed to be constant.

More than 2500 samples were analysed in the laboratory over a period of more than 4 years, and more than 13,000 results are now available for presentation and discussion. Since there were usually less than thirty results, or sets of results, 
from any individual season or cycle, statistical treatment of these results was considered unwise. The figures presented in the subsequent tables are geometrical means which are acceptable in standard practice, and which eliminate the effect: of excessively high or excessively low individual results. The figures should be sufficiently close approximations to average results, and as such sufficiently accurate as to be of significance. The individual figures in the tables are geometrical means from a minimum of twelve to fifteen samples, and a maximum of sixty samples.

To express the degree of purification attained in a conventional sewage treatment plant and in biological purification units, and to assess the extent of pollution in a river, organisms of faecal origin, i.e. Esch. coli in conjunction with faecal streptococci, were used as indicators. The rather vague indications given by determinations of the coliform group as a whole cannot be considered as fully satisfactory.

Kabler (1957) states in a review of the problem that coliform organisms are normally present in the faeces of all warm-blooded animals; that some coliforms are to be found on plants and grains; that faeces contain from 5 to 500 million coliforms per gramme, about $60-95 \%$ of which are $E s c h$. coli.

Aerobacter aerogenes, on the other hand, usually numbers $10,000-500,000$ per gramme of faeces, whereas the coliforms recovered from cultivated soil consist of $65-80 \%$ of $A$. aerogenes. Decaying plant material, or other organic compounds of non-faecal origin (Report, 1948), like sugars, may support the growth of considerable numbers of coliform organisms which are then obviously of very little, if any, sanitary significance. On the other hand, in the case of cultivated soil which has been treated with manure or compost, a large proportion of the coliform organisms present may be of faecal origin. In more general terms, the predominance of one type of organism over another depends to a large extent on environmental conditions and circumstances. Whereas the origin of coliform organisms is obvious in the case of sewage, it is somewhat more difficult in the study of effluents from biological purification units and in the assessment of pollution of rivers to decide on the origin of the organisms present.

Lactose broth alone may not be sufficient to provide a correct indication as to the number of coliform organisms present, but it will show the presence of slow lactose fermenters which do not fall into the coliform group, and will therefore contribute to the differentiation of the bacterial population.

Brilliant green bile-salt lactose broth is the ideal medium for the coliform group as a whole, but it does not permit of any conclusions as to the origin of the organisms present.

MacConkey broth, on the other hand, is specific for Esch.coli, both from human sources and from the faeces of warm-blooded animals, and is therefore the obvious choice for the determination and assessment of faecal pollution. In conjunction with a test for the presence of faecal streptococci the determination of Esch. coli should be accepted as the only criterion of faecal pollution, especially if it can be established that there is a constant numerical relation between Esch. coli and faecal streptococci. 
Koser's citrate medium is claimed to be specific for A. aerogenes, a member of the coliform group which is usually considered as non-faecal in origin. Esch. coli is not capable of growing in this medium, but it appears possible that the medium supports the growth of organisms not belonging to the coliform group, and possibly not of faecal origin, most of them characterized by the production of green and blue pigments.

Theoretically, the number of organisms capable of growing in MacConkey broth with the number of organisms capable of utilizing citrate should add up to the number of organisms belonging to the coliform group as determined by brilliant green bile-salt lactose broth, if one allows for deviations caused by the presence of atypical coliforms and intermediates like A. cloacae, Esch. intermedia and Esch. freundii, and for the occasional occurrence of non-coliforms. In practice, however, this calculation does not prove correct, mainly owing to the fact that fermentation tube tests supply only Most Probable Numbers, and due to the inherent weakness of this method.

The sanitary quality of waters, therefore, is dependent not on the total number of coliform organisms present, but on the number of Esch. coli present, as determined by the use of MacConkey broth. The use of lactose broth, brilliant green bile lactose broth and Koser's citrate medium in parallel supplies valuable information as to the actual composition of the total population and permits a definite differentiation into organisms of faecal and non-faecal origin which is of special importance in the assessment of river pollution.

\section{THE EFFECT OF CONVENTIONAL TREATMENT ON BACTERIAL POPULATIONS}

In order to obtain a basis for comparative studies of the efficiency of conventional sewage treatment and of further biological purification, as far as reductions in bacterial numbers are concerned, samples of sewage and sewage effluents in various stages of conventional sewage purification have been analysed regularly in parallel with effluents from biological purification units. It must be stated, however, that some of the disposal works from which these samples were collected were usually overloaded, and that the final effluents therefore were not of a particularly high standard. Whereas the percentage reductions recorded are in agreement with those found by Allen and his co-workers (Allen, Tomlinson \& Norton (1944); Allen, Brooks \& Williams (1949)), the actual numbers of organisms are higher than those reported from England. This may in part be due to the fact that the purification plants at Johannesburg and Pretoria were overloaded, and in part perhaps to the fact that water consumption per head of population is lower in South Africa, in zonsequence of which the sewage is more concentrated. Practically all samples from the various stages of treatment were taken at peak hours in the early morning, at approximately 9 a.m.

\section{Biological filtration}

Average figures and percentage reductions in bacterial numbers for the Cydna Sewage Disposal Works, Johannesburg, are given in Table 1. 
Table 1. Reduction in bacterial numbers by biological filtration, humus tank sedimentation and sand filtration at Cydna Sewage Disposal Works, Johannesburg

$\begin{array}{lccc} & \text { (Organisms per ml.) } & & \\ & \text { Lactose } & \text { Coliform } & \text { Faecal } \\ \text { fermenters } & \text { group } & \text { Esch. coli } \\ \text { Settled sewage } & 801,700 & 696,900 & 451,500 \\ \text { Biological filter effluent } & 60,770 & 50,660 & 18,680 \\ \text { Reduction (\%) } & 92 \cdot 4 & 92 \cdot 7 & 95 \cdot 9 \\ \text { Biological filter effluent } & 60,770 & 50,660 & 18,680 \\ \text { Humus tank effluent } & 11,610 & 13,900 & 3,000 \\ \text { Reduction (\%) } & 80 \cdot 9 & 72 \cdot 6 & 83 \cdot 9 \\ \text { Humus tank effluent } & 11,610 & 13,900 & 4,990 \\ \text { Sand-filter effluent } & 4,753 & 5,563 & 2,263 \\ \text { Reduction (\%) } & 72 \cdot 6 & 67 \cdot 0 & 54 \cdot 5 \\ \text { Overall reduction } & & & \\ \text { Settled sewage } & 801,700 & \mathbf{6 9 6 , 9 0 0} & 451,500 \\ \text { Sand-filter effluent } & 4,753 & 5,563 & \mathbf{2 , 2 6 3} \\ \text { Reduction (\%) } & \mathbf{9 9} \cdot 4 & 99 \cdot 2 & 99 \cdot 5\end{array}$

Treatment at Cydna consists of primary sedimentation, biological filtration, secondary sedimentation (humus tank), and final sand filtration. The effluent is discharged into the Zandfontein Spruit, a tributary of the Jukskei River (see map,

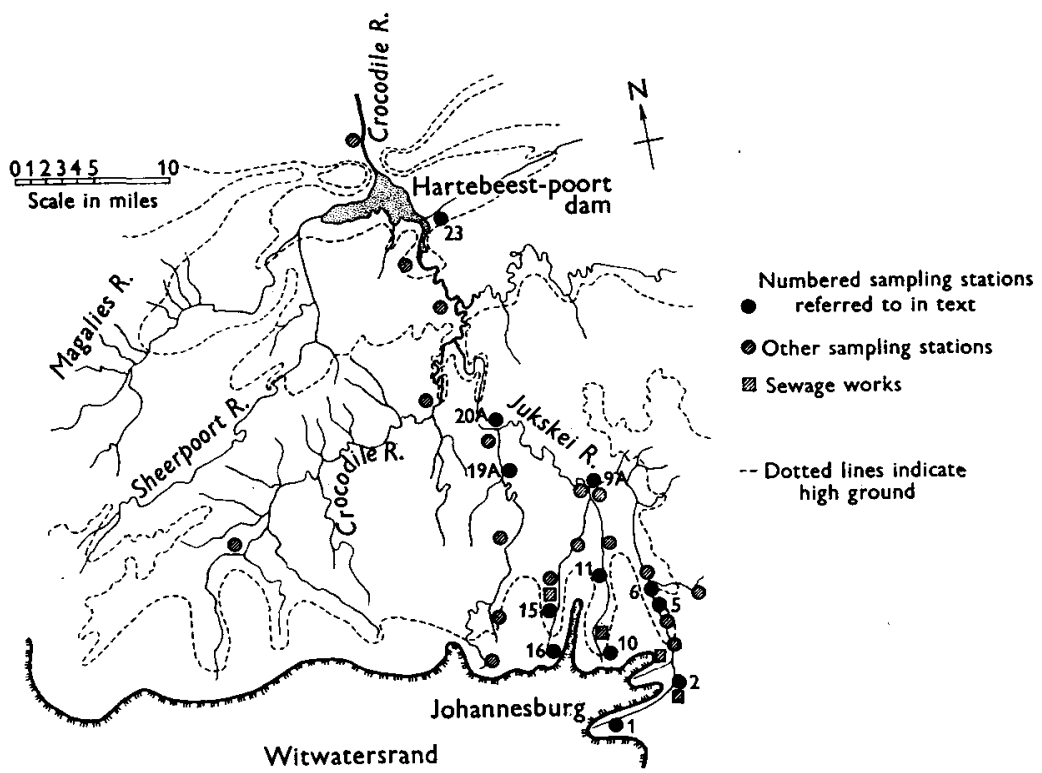

Fig. 1. The Jukskei--Crocodile River system.

Fig. 1, immediately north of sampling station no. 10). Complete treatment reduces the number of $E s c h$. coli from 451,500 to 2263 , or by $99.5 \%$; but the final effluent still contains more than 2000 organisms per $\mathrm{ml}$. 


\section{Activated sludge process}

Reduction in bacterial numbers effected by the activated sludge process were studied at the Delta and Bruma Sewage Disposal Works, Johannesburg, where settled sewage is treated, and at an experimental activated sludge plant at the Pretoria Sewage Works, where primary biological filter effluent is treated for further stabilization. The results are presented in Table 2.

Table 2. Reduction in bacterial numbers effected by the activated sludge process

\begin{tabular}{|c|c|c|c|c|c|}
\hline \multicolumn{6}{|c|}{ (Organisms per ml.) } \\
\hline & $\begin{array}{l}\text { Lactose } \\
\text { fermenters }\end{array}$ & $\begin{array}{l}\text { Coliform } \\
\text { group }\end{array}$ & $\begin{array}{c}\text { Faecal } \\
\text { streptococci }\end{array}$ & $\begin{array}{l}\text { Non-faecal } \\
\text { coliforms }\end{array}$ & $\begin{array}{c}\text { Faecal } \\
\text { Esch. coli }\end{array}$ \\
\hline \multicolumn{6}{|l|}{ Bruma } \\
\hline Influent* & 168,600 & 84,290 & 4,202 & 78,300 & 26,600 \\
\hline $\begin{array}{l}\text { Effluent (after humus } \\
\text { tank sedimentation) }\end{array}$ & 885 & 676 & 13 & 874 & 77 \\
\hline Reduction ( \%) & $99 \cdot 5$ & $99 \cdot 2$ & $99 \cdot 7$ & $99 \cdot 9$ & $99 \cdot 7$ \\
\hline \multicolumn{6}{|l|}{ Delta } \\
\hline Influent* & 156,900 & 95,680 & 14,710 & 52,830 & 19,730 \\
\hline $\begin{array}{c}\text { Effluent (after humus } \\
\text { tank sedimentation) }\end{array}$ & 1,203 & 766 & 105 & 766 & 279 \\
\hline Reduction (\%) & $99 \cdot 2$ & $99 \cdot 2$ & $99 \cdot 3$ & $98 \cdot 6$ & $98 \cdot 6$ \\
\hline \multicolumn{6}{|l|}{ Pretoria } \\
\hline $\begin{array}{l}\text { Influent (primary } \\
\text { biological filter effluent) }\end{array}$ & 56,850 & 54,380 & 11,240 & 24,510 & 47,220 \\
\hline $\begin{array}{l}\text { Effluent (after humus } \\
\text { tank sedimentation) }\end{array}$ & 3,087 & 2,111 & 713 & 2,330 & 1,871 \\
\hline Reduction (\%) & $94 \cdot 6$ & $96 \cdot 1$ & $93 \cdot 7$ & $90 \cdot 5$ & $96 \cdot 0$ \\
\hline
\end{tabular}

Treatment of settled sewage by the activated sludge process and subsequent clarification reduces the number of Esch. coli by $99 \cdot 7$ (Bruma) and $98.6 \%$ (Delta) respectively; the effluent still contains more than 75 (Bruma) and more than 250 (Delta) organisms per ml.

The experimental aeration plant at Pretoria reduced the number of Esch. coli in primary biological filter effluent, depending on the load and the rate of recirculation, by $91 \cdot 6-97 \cdot 7 \%$; the effluent still contained between 500 and 4500 organisms per $\mathrm{ml}$. The figures used in Table 2 are averages from five experimental cycles.

\section{Sand filtration}

Since sand-filter effluent is usually considered as final and fit for discharge into a river, a comparative study of sand-filter efficiency has been carried out, using effluents from various types of sand filters at several sewage disposal works in the Witwatersrand area. The sand filters at Cydna, Klipspruit and Brakpan are slow sand filters of more or less the same design. Sandringham uses a Hamlin filter, also a type of slow sand filter. Springs uses rapid gravity filters. The results of this comparative study are presented in Table 3. 
Table 3. Reduction in bacterial numbers by sand-filtration

\begin{tabular}{|c|c|c|c|c|}
\hline \multicolumn{5}{|c|}{ (Organisms per ml.) } \\
\hline & $\begin{array}{l}\text { Total } \\
\text { count }\end{array}$ & $\begin{array}{l}\text { Lactose } \\
\text { fermenters }\end{array}$ & $\begin{array}{l}\text { Coliform } \\
\text { group }\end{array}$ & $\begin{array}{c}\text { Frocal } \\
\text { Esch. coli }\end{array}$ \\
\hline \multicolumn{5}{|l|}{ Cydna } \\
\hline Humus tank effluent & 262,530 & 17,286 & 16,866 & $\mathbf{4 , 9 9 0}$ \\
\hline Sand-filter effluent & 440,530 & 4,735 & 5,563 & 2,263 \\
\hline Reduction (\%) & 0 & $72 \cdot 6$ & $67 \cdot 0$ & $54 \cdot 4$ \\
\hline \multicolumn{5}{|l|}{ Delta } \\
\hline Humus tank effluent* & 500,450 & 37,655 & 24,310 & 17,390 \\
\hline Sand-filter effluent & 344,750 & 20,970 & 24,335 & 5,667 \\
\hline Reduction (\%) & $31 \cdot 1$ & $44 \cdot 3$ & $\mathbf{0}$ & $67 \cdot 4$ \\
\hline \multicolumn{5}{|l|}{ Klipspruit } \\
\hline Humus tank effluent & 968,000 & 16,365 & 19,056 & 3,462 \\
\hline Sand-filter effluent & 118,100 & 4,782 & $\mathbf{3 , 5 4 8}$ & 1,793 \\
\hline Reduction (\%) & 87.8 & $70 \cdot 8$ & $81 \cdot 4$ & $48 \cdot 2$ \\
\hline \multicolumn{5}{|l|}{ Sandringham } \\
\hline Humus tank effluent & $1,051,850$ & 26,940 & 8,010 & 6.647 \\
\hline Sand-filter effluent & 490,450 & 5,339 & 4,226 & 4,287 \\
\hline Reduction (\%) & $53 \cdot 4$ & $80 \cdot 6$ & $39 \cdot 7$ & $35 \cdot 5$ \\
\hline \multicolumn{5}{|l|}{ Brakpan } \\
\hline Humus tank effluent & 206,550 & 7,662 & 9,325 & 5,006 \\
\hline Sand-filter effluent & 54,695 & 5,026 & 2,626 & 752 \\
\hline Reduction (\%) & $73 \cdot 5$ & $34 \cdot 4$ & $71 \cdot 8$ & $85 \cdot 0$ \\
\hline \multicolumn{5}{|l|}{ Springs } \\
\hline Humus tank effluent & 170,550 & 4,729 & 2,270 & 881 \\
\hline Sand-filter effluent & 19,695 & 1,695 & 1,592 & 231 \\
\hline Reduction (\%) & $88 \cdot 5$ & $64 \cdot 2$ & $29 \cdot 9$ & $73 \cdot 8$ \\
\hline
\end{tabular}

Sand filtration reduces the number of Esch. coli in humus tank effluent by $35 \cdot 5-85 \cdot 0 \%$; the effluents still containing between 200 and 5000 organisms per $\mathrm{ml}$.

It has been found that occasionally an overloaded and not particularly well cared-for sand filter produces an effluent with a total count higher than that of the incoming humus tank effluent, whereas the coliform components of the population are reduced in number. It must be assumed that under certain circumstances a sand filter will support a specific indigenous population, possibly soil organisms which are, in part at least, washed out of the filter with the effluent and which tend to increase the total count. This is one instance where an increase in total count has no relation whatsoever to the pollutional load which actually has decreased.

The figures in the preceding tables cover all aspects of conventional sewage treatment. They were obtained to form a basis for comparison. They will be referred to later when the relative efficiency of conventional treatment and of further treatment in biological purification units is discussed. 


\section{FURTHER BIOLOGICAL PURIFICATION}

Various types of units for further biological purification have been tested in largescale experiments at the Cydna Sewage Disposal Works, Johannesburg, and at the Pretoria Sewage Disposal Works. Between December 1953 and February 1957 six circuits were investigated at Cydna, and between June 1954 and March 1958 ten circuits were studied at Pretoria. These circuits consisted of combinations of grass-plots and shallow ponds covered with dense vegetation, of algal beds and model rivers, and finally of dams and maturation ponds. The results obtained from a typical run at Cydna are presented in Table 4, those from a Pretoria circuit in Table 5.

Table 4. Further biological purification: Cydna circuit

\begin{tabular}{|c|c|c|c|c|}
\hline \multicolumn{5}{|c|}{ (Organisms per ml.) } \\
\hline & $\begin{array}{l}\text { Total } \\
\text { count }\end{array}$ & $\begin{array}{l}\text { Lactose } \\
\text { fermenters }\end{array}$ & $\begin{array}{l}\text { Coliform } \\
\text { group }\end{array}$ & $\begin{array}{c}\text { Faecal } \\
\text { Esch. coli }\end{array}$ \\
\hline $\begin{array}{l}\text { Humus tank effluent } \\
\text { Sand-filter effluent* } \\
\text { Reduction (\%) }\end{array}$ & $\begin{array}{r}2,599,000 \\
1,535,000 \\
40 \cdot 04\end{array}$ & $\begin{array}{l}48,740 \\
3,878 \\
92 \cdot 05\end{array}$ & $\begin{array}{l}20,850 \\
3,715 \\
82 \cdot 19\end{array}$ & $\begin{array}{c}10,270 \\
848 \\
91 \cdot 75\end{array}$ \\
\hline $\begin{array}{l}\text { Sand-filter effluent } \\
\text { Fishpond II } \\
\text { Reduction (\%) }\end{array}$ & $\begin{array}{r}1,535,000 \\
338,200 \\
77 \cdot 97\end{array}$ & $\begin{array}{l}3,878 \\
1,800 \\
553 \cdot 59\end{array}$ & $\begin{array}{l}3,715 \\
1,173 \\
\quad 68 \cdot 43\end{array}$ & $\begin{array}{l}848 \\
571 \\
32 \cdot 63\end{array}$ \\
\hline $\begin{array}{l}\text { Fishpond II } \\
\text { Vlei } \\
\text { Reduction (\%) }\end{array}$ & $\begin{array}{l}338,200 \\
3,558 \\
98 \cdot 05\end{array}$ & $\begin{array}{l}1,800 \\
34 \\
98 \cdot 10\end{array}$ & $\begin{array}{l}1,173 \\
42 \\
86 \cdot 42\end{array}$ & $\begin{array}{c}571 \\
3 \\
99 \cdot 41\end{array}$ \\
\hline $\begin{array}{l}\text { Vlei } \\
\text { Algal bed } \\
\text { Reduction (\%) }\end{array}$ & $\begin{array}{r}3,558 \\
15,640 \\
0\end{array}$ & $\begin{array}{l}34 \\
13 \\
63 \cdot 16\end{array}$ & $\begin{array}{l}42 \\
9 \\
78 \cdot 34\end{array}$ & $\begin{array}{c}3 \\
1 \\
76 \cdot 47\end{array}$ \\
\hline $\begin{array}{l}\text { Algal bed } \\
\text { Fishpond I } \\
\text { Reduction (\%) }\end{array}$ & $\begin{array}{r}15,640 \\
149,700 \\
0\end{array}$ & $\begin{array}{r}13 \\
119 \\
0\end{array}$ & $\begin{array}{r}9 \\
88 \\
0\end{array}$ & $\begin{array}{r}1 \\
43 \\
0\end{array}$ \\
\hline $\begin{array}{l}\text { Overall reduction } \\
\text { Humus tank effluent } \\
\text { Fishpond I } \\
\text { Reduction (\%) }\end{array}$ & $\begin{array}{r}2,599,000 \\
149,700 \\
94 \cdot 25\end{array}$ & $\begin{array}{l}48,740 \\
119 \\
99 \cdot 76\end{array}$ & $\begin{array}{l}20,850 \\
88 \\
99 \cdot 58\end{array}$ & $\begin{array}{r}10,270 \\
43 \\
99 \cdot 59\end{array}$ \\
\hline
\end{tabular}

The results from these investigations can be summarized as follows:

Vegetation ponds (Vleis)

The degree of reduction in bacterial numbers attained in a vegetation bed $(v l e i)$ is igh. The number of Esch. coli in humus-tank effluent was reduced by $98 \cdot 0-99 \cdot 6 \%$; ihe effluent containing from 40 to 100 organisms per ml. In sand-filter effluent, eduction in the number of Esch. coli by passage through a vlei amounted to between 38.4 and $99.4 \%$; the effluent containing between 5 and 6 organisms per ml. 
Table 5. Further biological purification: Pretoria circuit

\begin{tabular}{|c|c|c|c|c|}
\hline \multicolumn{5}{|c|}{ (Organisms per ml.) } \\
\hline & $\begin{array}{c}\text { Lactose } \\
\text { fermenters }\end{array}$ & $\begin{array}{l}\text { Coliform } \\
\text { group }\end{array}$ & $\begin{array}{l}\text { Non-faecal } \\
\text { coliforms }\end{array}$ & $\begin{array}{l}\text { Faecal } \\
\text { Esch. coli }\end{array}$ \\
\hline Humus tank effluent* & 195,400 & 142,900 & 74,460 & 121,700 \\
\hline Vlei & 635 & 977 & 2,400 & 327 \\
\hline Reduction (\%) & $99 \cdot 68$ & $99 \cdot 32$ & $96 \cdot 78$ & $99 \cdot 72$ \\
\hline Vlei & 635 & 977 & 2,400 & 327 \\
\hline Grass-plots & 9,340 & 8,370 & 6,539 & 3,458 \\
\hline Reduction ( \%) & 0 & 0 & 0 & $\mathbf{0}$ \\
\hline Grass-plots & 9,340 & 8,370 & 6,539 & 3,458 \\
\hline Algal bed & 4,285 & 3,215 & 21,300 & 1,285 \\
\hline Reduction (\%) & $54 \cdot 13$ & $61 \cdot 59$ & 0 & 62.84 \\
\hline Algal bed & 4,285 & 3,215 & 21,300 & 1,285 \\
\hline Fishpond & 77 & 125 & 2,170 & 21 \\
\hline Reduction (\%) & $98 \cdot 22$ & $96 \cdot 11$ & $89 \cdot 82$ & $98 \cdot 21$ \\
\hline Fishpond & 77 & 125 & 2,170 & 21 \\
\hline Model river & 1,293 & 547 & 4,645 & 2 \\
\hline Reduction (\%) & 0 & 0 & 0 & $88 \cdot 30$ \\
\hline \multicolumn{5}{|l|}{ Overall reduction } \\
\hline Humus tank effluent & 195,400 & 142,900 & $\mathbf{7 4 , 4 6 0}$ & 121,700 \\
\hline Model river & 1,293 & 547 & 4,645 & 2 \\
\hline Reduction (\%) & $99 \cdot 34$ & $99 \cdot 62$ & $93 \cdot 77$ & 99.99 \\
\hline
\end{tabular}

\section{Algal beds}

The degree of reduction in bacterial numbers attained in an algal bed is high if the bed is used as the first unit in a series of experimental installations for the further biological purification of a sewage effluent. If used after preliminary vlei purification, there is no further improvement, but usually a deterioration in bacteriological quality. Algal beds did not appear to be particularly effective in the reduction of bacterial numbers, and it appears doubtful if their inclusion in their present form in a circuit of units for further biological purification should be recommended.

Usually the purification process through the various units of a circuit continued progressively. Algal beds frequently did not contribute to this uninterrupted progress because in part an algal bed probably offers particularly favourable conditions for the survival and reproduction of a wide variety of micro-organisms, and also perhaps because the algal beds under observation never reached their climax during the period of time allowed for any individual cycle.

\section{Grass-plots}

Grass-plots usually effected good bacterial removal in the initial stages of an experimental run. Very soon, however, this straining effect was lost, and little, if any, purification would be accomplished. Grass-plots, on the whole, were more effective than algal beds, although inferior to vleis.

The chief difficulty with grass-plots, as well as to a lesser extent with vegetation 
beds, is the unavoidable gradual accumulation of humus on the plants and at the bottom of the experimental unit which in time leads to anaerobic conditions and renders the unit ineffective as far as reduction in bacterial numbers is concerned.

\section{Model rivers}

The use of model rivers did not support the contention that in this rather oversimplified duplication of what is supposed to constitute natural conditions, further biological purification, comparable to natural self-purification, could be attained. Obviously faunal and floral associations in a natural stream are somewhat different from the limited biota of a highly artificial structure which was supposed to be capable of taking over the fundamentally different function of self-purification in a natural stream. It is possible that for the same reason artificial vleis failed and did not produce the effects that were expected on the basis of results obtained in the survey of a natural vlei (Harrison, Keller, Dimovic \& Cholnoky (1959)).

\section{Oxidation ponds}

The use of existing pond facilities at Cydna did not contribute materially to the objectives of the study. Pond treatment of sand-filter effluent usually improved its quality, but in the case of effluents from the units for further biological purification at Cydna no further improvement was achieved; on the contrary, there was evidence of deterioration in the bacteriological quality. These ponds were largely ineffective on account of the fact that they were unsuitable for experimental purposes and completely surrounded by trees.

At Pretoria, the passage of effluents through a primary, and subsequently through a secondary maturation pond, improved their final quality. These ponds were specially constructed for this series of experiments. Table 6 presents results obtained by the treatment of primary biological filter effluent in maturation ponds.

Table 6. Reduction in bacterial numbers by maturation pond treatment

(Organisms per ml. P.F.E. = primary biol-filter effluent.)

\begin{tabular}{lccccc} 
& Lactose & Coliform & Faecal & Non-faecal & Faecal \\
& fermenters & group & streptococci & coliforma & Esch. coli \\
P.F.E. & 20,120 & 44,570 & 9,458 & 22,170 & 41,440 \\
Pond I & 1,327 & 843 & 216 & 1,835 & 604 \\
Reduction (\%) & $93 \cdot 4$ & $98 \cdot 1$ & $97 \cdot 7$ & $91 \cdot 7$ & $98 \cdot 5$ \\
Pond I & 1,327 & 843 & 216 & 1,835 & 604 \\
Algal bed & 483 & 456 & 113 & 744 & 201 \\
Reduction (\%) & $63 \cdot 6$ & $46 \cdot 0$ & $47 \cdot 6$ & $59 \cdot 5$ & $66 \cdot 8$ \\
Algal bed & 483 & 456 & 113 & 744 & 201 \\
Pond II & 128 & 75 & 14 & 343 & 8 \\
Reduction (\%) & $73 \cdot 5$ & $83 \cdot 5$ & $87 \cdot 7$ & $53 \cdot 9$ & $95 \cdot 9$ \\
Overall reduction, therefore: & \multicolumn{4}{c}{} & \\
P.F.E. & 20,120 & 44,570 & 9,458 & 22,170 & 41,440 \\
Pond II & 128 & 75 & 14 & 343 & 8 \\
Reduction (\%) & $99 \cdot 4$ & $99 \cdot 8$ & $99 \cdot 9$ & $98 \cdot 4$ & $99 \cdot 9$ \\
* The primary biological filter effluent used for the various experimental cycles at the \\
Tretoria Sewage Works varied considerably in bacteriological quality during the period under
\end{tabular}


Final treatment of primary biological filter effluent in a maturation pond reduced the number of Esch. coli by $99 \cdot 7-99.9 \%$; the effluent containing less than 10-26 organisms per ml. Final treatment of humus tank effluent in a dam or maturation pond reduced the number of $E s c h$. coli by $99.99 \%$; the effluent containing less than 1 organism per $\mathrm{ml}$.

\section{SELF-PURIFICATION AND THE EFFECT OF DRAINAGE AND RUN-OFF}

Concurrently with a comparative study of the reduction in bacterial numbers in the various stages of conventional sewage treatment, and with experimental studies on further biological purification, a survey of a river system has been conducted with the object of assessing the effect of the discharge of sewage effluents from conventional treatment plants into a natural stream. The river in question is the Jukskei (see map, Fig. 1) which drains the area of greater Johannesburg towards the north and flows into the Hartebeestpoort Dam. The main stream receives the effluent from the Bruma Sewage Disposal Works; two tributaries, the Zandfontein and the Braamfontein, receive the effluents from Cydna and Delta Sewage Disposal Works respectively, while the Klein Jukskei, another major tributary, is free from sewage pollution. A detailed report on this river survey will be published elsewhere (Allanson, 1959).

The survey of the Jukskei system, which is shown on the map of Fig. 1, started in October 1955, and had been completed by the end of 1958. Three rainy reasons and three dry seasons have been covered, and sufficient data have been accumulated to form a clear picture of conditions prevailing along the course of the river, and to build up a set of references for future use.

The conclusions presented in the following paragraphs were not arrived at merely on the basis of the bacteriological analysis of samples, but far more on an intimate knowledge of local conditions at the various sampling points which had been acquired during the time of the investigation. The bacteriological analysis, to a certain extent, served only to confirm the opinions formed as to the topographical conditions at any individual sampling point, and to supply exact quantitative information as to prevailing sanitary conditions.

Twelve sampling stations from a total of twenty-seven have been selected to illustrate the variety of conditions which exist along the course of the Jukskei River and its tributaries.

The seasonal variations encountered at these sampling points have been presented in block diagrams (Fig. 2). The diagrams show the percentage distribution of the organisms determined quantitatively by the methods discussed, and do not include total counts. It will be seen from these graphical presentations that during the dry season, in general, the percentage proportion of organisms of faecal origin is higher than during the rainy season. On the other hand, during the rainy season the percentage proportion of non-faecal coliform organisms increases. These seasonal variations show clearly that during the dry season faecal and/or sewage pollution becomes more pronounced due to lack of dilution of the sewage effluents 
which are discharged into the river; they also show that the run-off in the rainy season from areas adjacent to the river does not contribute materially to the faecal flora of the river, but that it adds coliform organisms of soil and plant origin.

The stations selected for graphical presentation are discussed individually.
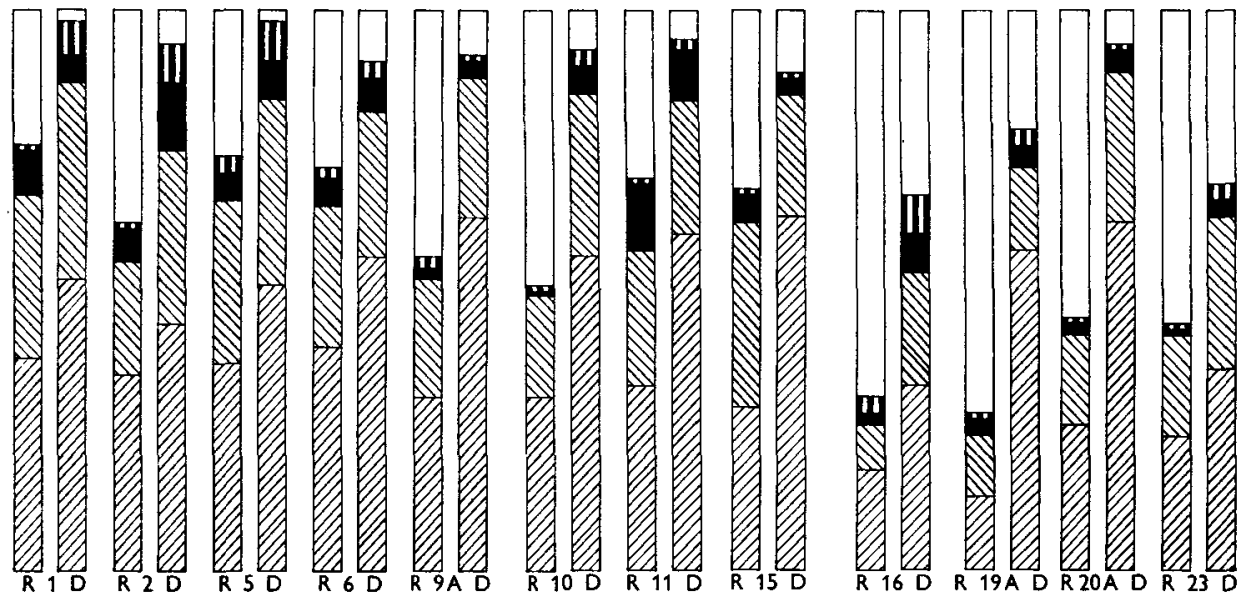

Fig. 2. Seasonal variation in percentage distribution of the organisms, determined quantitatively by the methods described, at the twelve sampling stations identified as numbered stations in the map (Fig. 1). $R=$ rainy season; $D=$ dry season; 1, 2, etc., stations; $\square$, nonfaecal coliforms; 四, faecal streptococci; $\square$, faecal Esch. coli; $\mathbb{N}$, coliform group; $\square$, lactose fermenters.

\section{Station 1}

The drainage area is mainly residential and partly industrial. There is no sewage pollution, but the probability of incidental faecal pollution, due to the defecatory habits of Africans, is high. In addition, effluents from laundries, dry-cleaning works and other 'light' industries reach the river directly. During the rainy season, runoff from market gardens is added to these. The river is, from a bacteriological point of view, polysaprobic, but not on account of the discharge of sewage effluents. During the rainy season, the bacterial population increases, but there is no appreciable increase in the number of $E s c h$. coli.

\section{Station 2}

The drainage area is recreational and includes a picnic spot; it is also used for cattle grazing. The station is situated approximately one mile below the outfall of a sewage disposal works and the river carries sewage effluent, more often than not insufficiently settled effluent from an activated sludge plant. Additional incidental pollution is possible, but does not appreciably affect conditions. The water contains a fairly constant number of Esch. coli all the year round, on the average about 500 organisms per $\mathrm{ml}$.

\section{Station 5}

The drainage area is sparsely populated. Throughout the year the river receives seepage and run-off from a composting plant in which unsuccessful attempts are 
made to convert a mixture of night soil, manure and domestic refuse into compost by the addition of wood shavings and subsequent storage in pits. The number of $E s c h$. coli is on the average about 100, but increases after heavy rain to more than 300 organisms per ml. A few hundred yards below the composting plant sewage effluent from a social institution reaches the river, but the sewage is treated in septic tanks and French drains, and the effluent is used for the irrigation of vegetable and flower gardens. On reaching the river, it does not contribute to its pollution.

\section{Station 6}

The drainage area is sparsely populated, a peri-urban residential area with some agricultural activity. The probability of incidental faecal pollution is low. The river has to a large extent recovered from the effect of station 5, and the number of $E s c h$. coli is below 10 during the dry season and between 15 and 20 organisms per ml. during the rainy season.

\section{Station $9 \mathrm{~A}$}

The drainage area is extensively cultivated for crop production; heavy manuring, partly with composted material, is practised. There is a very high probability of incidental faecal pollution, and after heavy rain there may be a sudden temporary increase in the number of Esch. coli, but on the whole the figure is fairly constant at about 15 organisms per $\mathrm{ml}$. throughout the year.

\section{Station 10}

The drainage area comprises residential suburbs and includes a golf course. Incidental faecal pollution is remotely possible. The number of Esch. coli is below 1 per ml. during the dry season; there is an increase during the rainy season to about 10 organisms per ml.

\section{Station 11}

The drainage area is purely residential; the topography of the region makes incidental faecal pollution improbable. Less than one mile above the sampling point, sewage effluent is discharged into the stream. There is very little seasonal variation in the number of Esch. coli present; on the average, there are about 400 organisms per $\mathrm{ml}$. throughout the year.

\section{Station 15}

The drainage area is residential and includes a complex of sports-grounds. During week-ends it serves as a gathering place for urbanized Africans, and the possibility of incidental faecal pollution is very high. During 1956-7, excavations and building activities on a large scale took place, and at the same time the total count was well above 500,000 organisms per ml., higher than the average at sampling points below the outfalls of sewage disposal works. The high incidence of faecal pollution other than of sewage origin found expression in the number of Esch. coli present, usually in the vicinity of 500 organisms per $\mathrm{ml}$. 


\section{Station 16}

The drainage area was unpopulated when the survey started; it is now being built up, and excavations and building activities are in progress. There is the possibility of incidental faecal pollution. The number of Esch. coli does not vary appreciably during the course of the year, but over a period of 18 months the number has increased progressively from 0 to 6.5 organisms per $\mathrm{ml}$.

\section{Station $19 A$}

The drainage area is sparsely populated and comprises mainly small-holdings. Incidental faecal pollution appears to be negligible. There is a slight increase in the number of Esch. coli during the rainy season, probably due to run-off from cultivated and manured lands : the number of $E s c h$. coli increases to 2 organisms per ml., whereas it stays well below 1 during the dry season.

\section{Station $20 \mathrm{~A}$}

The drainage area is unpopulated; it is used, in part, however, to dispose of sewage effluent by irrigation, and particularly during the rainy season run-off reaching the river carries faecal pollution and causes a deterioration in the bacteriological quality of the river. Particularly after heavy rain the number of Esch.coli increases, and during the period under observation averages have increased from less than 1 to more than 30 organisms per $\mathrm{ml}$.

\section{Station 23}

The drainage area is sparsely populated and serves in part for recreational purposes. The probability of incidental faecal pollution is not very high. On the whole, the bacteriological quality of the water is good. There is an increase in the total count during the rainy season, but there is no corresponding increase in the number of Esch. coli, which usually remains below 1 organism per ml. throughout the year.

Summarizing these observations it appears that generalization is impossible, and that the final effect of self-purification, as well as the effects of drainage and run-off depend entirely on the conditions prevailing in the respective drainage areas and on the quality of the run-off which reaches the river along its course.

\section{CONCLUSIONS}

1. From the results of studies of the efficiency in reduction of bacterial numbers shown by conventional sewage treatment plant in comparison with the effectiveness of units for further biological purification it appears justifiable to assert that the experimental work reported here shows new ways in the treatment of sewage effluents for final discharge into streams.

2. Certain individual units, like artificial vleis, are far more efficient in the reduction of bacterial numbers than are sand filters. At Cydna, in practically all instances reductions were higher than $90 \%$, as compared with a sand-filter 
efficiency from below 30 to a maximum of $87 \cdot 8 \%$. Similar results were obtained with grass-plots and maturation ponds at Pretoria, where the coliform group was reduced to less than $1 \%$, with the exception of organisms of possibly non-faecal origin which remained at a level of $3.22 \%$. In fact, sand-filter effluent came up to the standard obtainable by methods of further biological purification only after chlorination.

3. Considering, however, the difficulty of maintaining certain units at a constant high level of efficiency, it appears that the final solution will rest in the establishment of maturation ponds. At present, the substitution of sand filters by maturation ponds should be recommended whenever practicable.

4. Complete treatment of settled sewage up to the final sand-filter stage reduces the number of Esch. coli from more than 400,000 to less than 2500 organisms per $\mathrm{ml}$., effecting a reduction of more than $99 \%$. Sand-filter effluents, on the other hand, still contained between 200 and more than 5000 Esch. coli per ml., according to the comparative study reported here. In comparison with these figures, reduction in the number of Esch. coli effected in maturation ponds, where the final effluent contained between 1 and 10 organisms per ml., is far more satisfactory. It is obvious therefore that the discharge of maturation pond effluent into a river, from any point of view, is far less objectionable than the discharge of sandfilter effluent.

5. Summarizing the results obtained from the survey of a river into which sewage effluents are discharged, it must become evident that maturation-pond effluent would not only have a less deleterious effect on the river quality but would actually improve conditions in a river which, like the Jukskei, is subject to the influence of faecal pollution other than of sewage origin. Moreover, maturationpond effluent as such is frequently of better quality bacteriologically than the runoff which reaches the river from various areas during the rainy season.

6. The fact should be taken into account that densely populated areas may contribute considerably to the pollutional load of a river, in spite of proper sanitation and effective control by local authority. The self-purifying powers of the Jukskei River at Station 1 are severely strained by this type of incidental pollution which just cannot be avoided or eliminated. The discharge of conventionally treated sewage effluent above Station 2 increases the pollutional load still further, instead of effecting an improvement, which would be the case, however, if the sewage had undergone complete treatment up to the maturation-pond stage.

7. Under certain circumstances, if there is originally a high probability of incidental faecal pollution, and if the run-off from a drainage area carries a heavy pollutional load, there will be an increase in the degree of faecal pollution during the rainy season. This applies to the badly designed and inefficiently operated composting plant on the banks of the Jukskei; to run-off from extensively cultivated and heavily manured lands, where the defecatory habits of the African labourers constitute a further contributory factor; and to the use of partly treated sewage for irrigation.

8. Building activities, excavations, earth-moving operations, all contribute to substantial increases in the total count, and even to increases in the number of 
organisms belonging to the coliform group, but they do not contribute directly to faecal pollution. Similarly, accumulations of decaying plant material increases the number of coliforms, sometimes considerably, but it would be absurd to regard this type of pollution as faecal.

9. In unpopulated or sparsely populated areas, faecal pollution is usually practically absent. Only with increasing human activity, and with a correspondingly higher possibility of incidental faecal pollution, will the effect become evident in the river. But this effect will be consistent throughout the year, and will not exhibit seasonal variations due to run-off. The number of Esch. coli found under these conditions will be small and practically constant throughout the year.

\section{SUMMARY}

The National Institute for Water Research of the South African Council for Scientific and Industrial Research has been engaged on extensive research into the conservation of water supplies and into the reclamation of industrial and sewage effluents. Within the framework of this programme, a comparative study of the efficiency in the reduction of bacterial numbers by existing conventional sewage treatment plants has been carried out. The numerical decreases in bacterial populations after primary sedimentation, biological filtration, the activated sludge process, secondary sedimentation (humus tank), and final sand filtration have been compared with the reduction in bacterial numbers attained by the treatment of sand-filter effluent, humus tank effuent, and primary biological filter effluent in units for further biological purification.

Various types of units for this purpose have been investigated, and from available results it appears perfectly feasible to consider the suitability of effectively purified sewage effluents as sources for raw water supplies for industrial and domestic use. Sewage effluents after final further biological purification could be admitted for unrestricted discharge into rivers. The possibility of objections from the point of view of public health and future use is completely ruled out by the fact that the quality of the final effluent is as good as that of river water.

A variety of experimental units for further biological purification of sewage effluents have been studied, and a comparison of the results obtained from grassplots, artificial vleis (a natural vlei in South Africa is a marshy or swampy depression in the ground in which water collects and which supports a standing vegetation), algal beds, artificial model rivers, and maturation or oxidation ponds have shown that maturation ponds, possibly a number of ponds in series, with an established microflora and microfauna of their own, may provide the final solution of the problem. Further biological purification will play an important role in the conservation of water supplies and will contribute to the raw water sources available for industrial and domestic use.

In parallel with these studies, the effect of the discharge of sewage effluents from conventional treatment plants into a river system has been investigated together with the fate of the sewage bacteria after admission to a natural environment. The manifestations of self-purification have been recorded, and the additional or 
superimposed effect of run-off and drainage from populated and unpopulated areas, as well as the admission of storm-water, have been considered together with the effects of seasonal variations due to climatic conditions.

The author wishes to express his gratitude to his assistants who bravely bore the burden of the routine work involved, and wishes to thank the S.A. Council for Scientific and Industrial Research for permission to publish this paper.

\section{REFERENCES}

Allanson, B. R. (1959). A survey of the Jukskei-Crocodile river system. Part of a thesis submitted for Ph.D. degree, University of Cape Town.

Allen, L. A., Brooks, E. \& Wrllams, I. L. (1949). J. Hyg., Camb., 47, 303.

Allen, L. A., Tomlinson, T. G. \& Nonton, I. L. (1944). Surveyor (Dec.), p. 585.

Harrison, A. D., Keller, P., Dimovic, D. \& Cholnoky, B. J. (1959). Hydrobiologia (in the Press).

KABLER, P. (1957). Use and value of bacteriological indicators of pollution. In Biological Problems of Water Pollution. Washington: U.S. Dep. Publ. Hlth.

RePort (1948). Tri-state Survey of Lake Michigan Waters. Federal Security Agency, Public Health Service, Cincinnati, Ohio.

Stander, G. T. \& Gien, I. (1956). Wat. Sanit. Engr, 6, 108.

(MS. received for publication 24. VI. 59) 